\title{
Lisa Baraitser
}

\section{Time and Again: Repetition, Maternity and the Non-Reproductive}

What is the relation between reproduction, non-reproduction and time? In this short position piece, I'd like to revisit how we might conceptualize maternal time through some reflections on the temporalities of non-reproduction and its relation to the temporal trope of repetition.

To think about reproductive and non-reproductive time opens us onto a series of questions: Does non-reproduction, as a social signifier, always carry the burden of 'stilling' time? Is non-reproduction asked to bear an impossible relation to both the cyclical and monumental temporalities of female reproduction, and the masculine principles of teleological time? Or does non-reproductive time necessarily 'queer' reproductive and teleological time? If so, what are the reciprocal implications for maternal time? Is reproduction, and the maternal more broadly, evoked as the normative shadow of the deliberately 'stilled' or 'stalled' time of the non-reproductive, caught between the temporal rhythms of birth, regeneration, and death, and the dead 'progressive' narratives of departure and arrival? Can we use the trope of 'time that refuses to flow', or repetitive time, as a way to rethink maternity, queer and the death drive?

One very powerful articulation of the link between queer, time and the nonreproductive is Lee Edelman's polemic, No Future (Edelman 2004). Edelman pits developmental time (time that unfolds in relation to an ever receding yet hopeful future, figured culturally as the Child), against queer time, figured as the death drive. In tandem with Edelman's work, a whole battery of temporal tropes has emerged recently to describe nonnormative, non-developmental timelines: Elizabeth Freeman's notions of 'familial arrhythmia', 'erotohistoriography', and 'temporal drag' that she uses to propose alternative temporalities to what she calls 'heterochrononormativity' (Freeman 2011); Dana Luciano's term 'chronobiopolitics' which describes the normative temporal organizations of entire populations around capital, nation and the family (Luciano 2007); the historian Carla Freccero's 'queer spectrality', that functions as a phantasmic relation to historicity to account for the affective force of the past in the present (Freccero 2006); and Elizabeth Povinelli's 'durative present' that illuminates the ways marginal social projects endure in the seams of 
capitalism through alternative temporal practices (Povinelli 2011). Taken as a 'temporal turn' in cultural studies, this body of work draws attention to the ways that time 'binds' us (Freeman 2011) into specifically patterned lives, intimately linked to national narratives, capitalist economic logics, and timelines of birth, development, marriage, reproduction, the accumulation and passing on of wealth, and death.

Edelman argues that current communal relations in the West are organised through the absolute primacy of heteronormativity, so much so that the future can only be thought of in relation to the developmental sequence of such a normative timeline. Therefore, queer resistance to such an order can only show up as resistance in opposition to the Child. Rather than acceding to this dualism by protesting against this othered position in order to gain access to the social domain, Edelman proposes a deliberate identification with the figure who is indeed 'not fighting for the children'. In this way, queerness remains a radical form of nonidentity which attains its ethical value through an acceptance of its status as the 'outside' and 'beyond' of the social order's political symptoms which he names as the death drive. Queer is a refusal of any form of consolidated identity which is always linked to history as linear narrative, in which meaning reveals itself as itself, through time (Edelman 2004, p. 4). Over and over, Edelman says ' $n o$ ' through a paradoxical acceptance and embracing of the negativity assigned to queer, and over and over, the ' $n o$ ', which takes the form of an embrace, of a yes, is directed at the temporal category of the future understood in linear developmental terms. The temporality of this refusal is not just that of repetition in the sense of the return of the repressed, but that of the constant. There can be no let up of the no. It is the ongoing, unrelenting negativity that also echoes the law of the Symbolic's 'foundational act, its selfconstituting negation' (Edelman 2004, p. 5). Whilst signification, which operates through the deferral of meaning, requires a projection forwards, a relationship we could say with the future, at the same time the death drive, which is also a function of the Symbolic, provides a constant negative force against even the possibilities of deferral. Queer can expose that constancy, the inescapability of access to jouissance in the social order itself.

Two issues arise from Edelman's conjoining of no with future that pertain to maternal time. The first is that we may be seeing a radical shift in the ways we imagine futures, so much so that the fantasy of an unfolding future held in place by heteronormative familial trajectories may no longer function as a dominant cultural narrative. Franco 'Bifo' Berardi, for instance, is one of many voices noting that we are now living in the 'end times' of late capitalism, which radically changes the ways in which we relate to narratives of progress and 
future (Berardi 2011a). For Berardi, our times are characterized by 'the cultural collapse of the most important mythology of capitalist modernity: that of "the future" and its associated myths of energy, expansion, and growth', (Berardi 2011b, non-paginated). We are 'postfuture', bereft of the fantasy of a progressive and open future which reached its peak in the second half of the $20^{\text {th }}$ century. This, Berardi argues, has been replaced by a generalised condition of acceptance of 'no future': permanent debt, climate catastrophe, declining biodiversity, perpetual conflict, resource scarcity and economic austerity for the planetary majority. 'No future' here signifies an infinitely expanding present. Berardi advises us to 'harmonize with exhaustion' (Berardi 2011b, non-paginated) - to accept the end of the fantasy of the future understood as development, growth, expansion, and accumulation, rather than embracing the death drive as the internal undoing of the fantasy, which shows up the fantasy as fantasy, but fails to recognize that the fantasy of an open future has already ended. In other words, we may no longer require the figure of the Child to suture an imaginary that has already collapsed.

The second issue has to do with feminism, the death drive and its relation to the temporality of repetition. Edelman's Lacanian death drive is a constant pressure created by an excess of access to jouissance, and has the temporal structure of eternal return with no movement, and no difference. Slavoj Zizek, writing in the same vein, describes the death drive in terms of the undead: 'this terrifying insistence beneath death, which is why Freud links death drive to the compulsion to repeat. You know, it can be dead, but it goes on' (Zizek 2006, p. 61). Here there is too much time, an endless and ongoing agonizing, yet pleasurable repetition, that paradoxically brings on more of the same. Yet if we return to Beyond the Pleasure Principle, for Freud this repetition is also a deviation. The life of an organism is figured as an ongoing deviation that seeks to maintain its existence by resisting any path to death that does not conform to its own particular limits and conditions for self-preservation. As Freud puts it, these conditions 'are component instincts whose function it is to assure that the organism shall follow its own path to death, and to ward off any possible ways of returning to inorganic existence other than those which are immanent in the organism itself ... what we are left with is the fact that the organism wishes to die only in its own fashion' (Freud 1922, p. 33). Though we repetitively return, we return to a particular place, utterly singular, in order to die in our own way. It is this tension, however, between the constant repetition of the death drive, and the truly repetitious, which incorporates the utterly singular, that we can see threaded through early feminist literature that sought to understand the place 
of reproduction in social life. Both Simone de Beauvoir (1948) and Hannah Arendt, (1958) for instance, discussed at length the relationship between repetitious, and hence 'meaningless' reproductive labour, and socially meaningful, productive 'work'. For both writers, for the 'singular' to emerge, we need to go beyond the simple maintenance and reproduction of life, and produce something durable, or express the self through creative activity (Veltman 2011). Repetition, and hence maternity, in this early work was seen as synonymous with the death drive; deadening, meaningless, an 'absurd vegetation' (De Beauvoir 1948, p. 83).

During the 1970's, this distinction between reproduction and production was revisited by Marxist feminists keen to recast 'meaningless' repetitive reproductive labour as productive of surplus value, and in fact the bedrock of capitalist production (Dalla Costa \& James 1973; Cox \& Federici 1976). Yet another strand of feminist thinking took repetitive reproductive labour, sociality, care and maintenance as models for viable ways to live a life. For instance Mierle Laderman Ukeles provides an example of a feminist intervention into the constancy of the death drive through her early artistic work that sought to raise the repetitive labour of care to the status of Art. Ukeles, who became pregnant whilst at art school in the late 1960's, was told by her art teacher that she therefore couldn't be an artist. Her response was to claim the naming of what is art as the artist's prerogative, and her daily tasks - cleaning, sweeping, washing, changing nappies, cooking and bed-changing -she declared as 'Maintenance Art'. In her 1969 Maintenance Manifesto Ukeles addressed how relational art interacts with the systemic substrates of material support in people's lives. Her manifesto looks at two basic systems, those of development and those of maintenance, which she claims are usually opposed, and linked to the death drive and the life instincts respectively in psychoanalysis. Ukeles noted the link between the animating drive of political protest, avant-garde art, and the subjective pleasures of the death drive in which one follows one's own path to death. The 'life' instinct, on the other hand, was relegated to the zone of uncreativity, and stuck to those with responsibility for maintaining the creativity of others - that is, reproduction. As the art critic Shannon Jackson puts it: 'sustain, reserve, protect, defend, prolong, renew, repeat, show your work again, keep the home fires burning' (Jackson 2011, p. 86).

So, working anachronistically, we could say that Ukeles provides a critique of Edelman's co-opting of political protest on the nether side of development. Indeed, to follow one's own path to death in the form of political protest that refuses all substantiation of selfidentity marginalizes the work of the maintenance of self-identity. Here a set of collective and relational practices are seen to bind us to the socius. Ukeles changes the direction of this 
trajectory - radicality lies not in the assertion of autonomous personhood, change and disruption, but in the habits of repetitive maintenance and care, on which such autonomy is dependent. For Ukeles, this was an epiphany: Survival is art, maintenance is art, repetition is art, reproduction is art. Going on to work as a self-appointed artist-in-residence in the New York Sanitation Department, walking out the city for a decade with those workers who were tasked with perpetual cleaning, Ukeles' maintenance work proposes an alternative temporal narrative to that of progress through the return to repetition as a kind of literalization of the social factory. If, according to Elizabeth Freeman, temporal narratives bind individuals into larger historical and national dynamics through ways that 'legitimate' normative social organizations live and orchestrate time, then Ukeles shows up the temporal maintenance practices of such social organizations. Through the insistence on a relationship between the museum, for instance, and the social site she is embedded in (the New York Sanitation Department) she also helps us rework our relationship to normative social institutions. What is important here is that repetition as a temporal trope and a form of social labour is made distinct from the death drive, figured as a monadic masculine drive for subjective pleasure. Repetition is linked with the radicality of care on which such autonomy is dependent.

In the light of this, I want to close with a reflection on the poet and historian, Denise Riley's Time Lived, Without its Flow, (Riley 2012) which charts the shift in how time is lived following the death of her adult son. Here, maternal or reproductive time is not so much the relentless repetition of the death drive, but a kind of crystalline time that refuses to flow, and that is revealed through the actual death of a child. Riley writes:

I'll not be writing about death, but about an altered condition of life. The experience that not only preoccupied but occupied me was of living in suddenly arrested time: that acute sensation of being cut off from any temporal flow that can grip you after the sudden death of your child. And a child, it seems, of any age. (Riley 2012, p. 6)

The temporal disordering that the death of an adult child prompts affects the capacity to narrativise, due to a changed relationship with the future that the unfolding of narrative in time requires. Riley is concerned with what it means for time to stop and time to flow, and for another kind of stopped time, the lively and prolonged time of the dead, to occupy lived time. Riley is clear that 'time stopped' is an inadequate metaphor for the prolonged time that is arrested after the death of an adult child. Although we can technically say that the time of the dead is timeless in that the dead cannot return and hence time as movement or change is somehow foreclosed by the ongoing deadness of the dead, one's engagement with a dead 
child, she maintains, is in fact lively. It is not the dead time, for instance, of depression; one continues to be involved on a day-to-day basis in an energetic way with the dead child.

Instead, it is one's relation to everyday life that goes through a dramatic shift, one in which time can no longer unfold predictably or reliably as a crisis has occurred in the reliability that the future will unfold. In one sense, time is 'crystalline', as she puts it, in which nothing flows because nothing can be expected, whilst at another it continues as a form of daily engagement with 'timelessness'. Time doesn't stop, but it doesn't develop either. It is simply suspended. Riley therefore poses the question of the philosophy of endurance, asking what it means to endure when there is no longer any temporality left in which to wait it out? Time here is not 'distorted':

What's changed is more radical than that. Simply, you are no longer in time. Only from your freshly removed perspective can you fully understand how our habitual intuitions of time can falter. (Riley 2012, p. 196)

You cannot register the underlying sense that time moves until its movement has collapsed. What is revealed then is a way of being outside of time's motion without being outside of time. Perhaps what's specific is this: that with the death of your child, your own time may be especially prone to disturbance, because the lost life had, so to speak, previously unfurled itself inside your own life. (Riley 2012, p. 255)

I read Riley's comments here as metaphorical of any life that could be said to unfurl itself inside your own life. It might be that any relation that we name as a relation with a child has this quality, someone that is of any age, and of any relation to another, but who has somehow, in some way unfurled itself inside your own life. Whilst narrative, the time of development, may falter, so a non-developmental relation to time, crystalline time, that is simultaneously stilled and yet lively persists. Riley unhooks time from development, allowing us to glimpse an aspect of maternal subjectivity that is not premised on the open future of the child, but the way motherhood requires a certain acceptance of what refuses development, what resists time. Though I would not want to suggest that relations with a dead child are identical to relations with a living child, this parallel register is one in which the maternal subject bears the suspension of time, a kind of impossible waiting which is the time the child's futurity requires of her. If one could write in these circumstances, then perhaps such writing would encode the time of maternal waiting as a certain kind of ethical labour.

The non of non-reproduction is not the same as the No of No Future. The non, in relation to the no-longer living adult child who has unfolded in relation to one's own time 
opens this crystalline time, time that is lived but does not flow. This is not the constant excessive time of the death drive as it deviates from life, and it's not the unfolding of a linear future, but something else that one may want to hold onto as a way to articulate the temporality of (non)-reproduction.

\section{References}

Arendt, H. 1958. The human condition. Chicago: University of Chicago Press.

Berardi, F., 2011a. After The Future, Eds. Gary Genosko and Nicholas Thoburn. AK Press: Edinburgh, Oakland, Baltimore.

Berardi, F., 2011b. The Future After the End of the Economy. Eflux: available at http://www.eflux.com/journal/the-future-after-the-end-of-the-economy/

Edelman, L., 2004. No Future. Edelman, L., (2004) No Future: Queer Theory and the Death Drive. Duke University Press: Durham and London.

Cox, N., \& Federici, S., 1976. Counter-Planning from the Kitchen: Wages for Housework, A Perspective on Capital and the Left. Brooklyn, NY: New York Wages for Housework Committee.

Dalla Costa, M, \& James, S., 1973. The Power of Women and the subversion of the Community. 2nd Ed. Bristol, UK: Falling Wall.

De Beauvoir, S, 1948. The ethics of ambiguity. Trans. Bernard Frechtman. New York: Citadel Press.

Freeman, E., 2010. Time Binds: Queer Temporalities, Queer Histories. Durham and London: Duke University Press.

Freud, S., 1922. Beyond the Pleasure Principle. The Standard Edition of the Complete Psychological Works of Sigmund Freud, Vol XVIII. Ed James Strachey. Vintage: The Hogarth Press, (2001).

Freccero, C., 2006. Queer/Early/Modern. Durham: Duke University Press, 2006.

Jackson, S., 2011. Social Works: Performing Art, Supporting Publics. New York and London; Routledge.

Luciana, D., 2007. Arranging Grief: Sacred time and the body in nineteenth-century America. New York University Press: New York and London.

Povinelli, E, A., 2011. Economies of Abandonment: Social Belonging and Endurance in Late Liberalism. Durham: Duke University Press.

Riley, D., 2012. Time Lived Without its Flow. Capsule Editions, London.

Ukeles, M.L., 1969. Manifesto for Maintenance Art 1969! Proposal for Exhibition 'Care': 1-4.

Veltman, A., 2010. Simone de Beauvoir and Hannah Arendt on Labor. Hypatia, 25(1): 55-78.

Zizek, S. 2006. The Parallax View. MIT Press: Cambridge, MA.

Lisa Baraitser, Time and Again: Repetition, Maternity and the Non-Reproductive 